\title{
Identification of MC4R gene and its association with body weight and body size in Kebumen Ongole Grade cattle
}

\author{
D. Maharani ${ }^{1, *}$, A. Fathoni ${ }^{1}$, Sumadi ${ }^{1}$, T. Hartatik ${ }^{1}$ and M. Khusnudin ${ }^{2}$ \\ ${ }^{1}$ Department of Animal Breeding and Reproduction, Faculty of Animal Science, \\ Universitas Gadjah Mada, Jl. Fauna 3 Bulaksumur, Yogyakarta 55281 - Indonesia \\ ${ }^{2}$ Association of Ongole Grade Cattle Breeder in Kebumen, \\ Tanggulangin Village, Klirong Subdistrict, Kebumen, Jawa Tengah - Indonesia \\ "Corresponding E-mail: d.maharani@ugm.ac.id
}

Received September 13, 2017; Accepted February 02, 2018

\begin{abstract}
ABSTRAK
Gen MC4R dikenal sebagai kandidat gen untuk sifat pertumbuhan. Penelitian ini bertujuan untuk mengidentifikasi gen MC4R pada sapi Peranakan Ongole (PO) Kebumen dan hubungannya terhadap sifat pertumbuhan ternak tersebut. Data bobot lahir (BL), bobot sapih (BS), panjang badan lahir (PBL), lingkar dada lahir (LDL), tinggi gumba (TG), panjang badan sapih (PBS), lingkar dada sapih (LDS), tinggi gumba sapih (TGS) dan rata-rata pertumbuhan bobot badan harian (ADG) digunakan untuk analisis asosiasi berdasarkan gen MC4R. Total 60 sampel darah diambil dan digunakan untuk isolasi DNA. Produk PCR diamplifikasi dengan menggunakan primer forward 5'GTCGGGCGTCTTGTTCATC-3' dan reverse 5' GCTTGTGTTTAGCATCGCGT-3'. Single Nucleotide Polymorphisms (SNP) g.1133 C > G digunakan untuk proses genotyping menggunakan metode PCRRFLP dengan enzim restriksi HpyCH4IV. Frekuensi alel G $(0,59)$ lebih besar dibandingkan dengan alel $\mathrm{C}(0.41)$. Frekuensi genotip tertinggi dimiliki oleh ternak bergenotip heterozigot $\mathrm{CG}$, diikuti dengan ternak bergenotipe homozigot GG $(0,33)$ dan CC $(0,15)$. Hasil uji Chi-square menunjukkan populasi tidak menyimpang $(\mathrm{P}>0,05)$ dari Hardy-Weinberg Equilibrium (HWE). Hasil analisis asosiasi menunjukkan bahwa SNP g. $1133 \mathrm{C}>\mathrm{G}$ pada gen MC4R berpengaruh nyata terhadap panjang badan lahir ternak dengan genotip GG $(\mathrm{P}<0,05)$. Kesimpulannya, SNP g.1133 $\mathrm{C}>\mathrm{G}$ dapat digunakan sebagai marker untuk seleksi sapi PO Kebumen berdasarkan sifat panjang badan saat lahir.
\end{abstract}

Kata kunci: sapi PO Kebumen, Gen MC4R, bobot badan, ukuran tubuh

\begin{abstract}
MC4R gene is known as an important candidate gene for the growth trait. The purpose of this research was to identify the $M C 4 R$ gene in Kebumen Ongole grade cattle and examine its association with growth traits. Data of birth weight (BW), weaning weight (WW), birth body length (BBL), birth chest circumference (BCC), birth shoulder height (BSH), weaning body length (WBL), weaning chest circumference (WCC), weaning shoulder height (WSH) and average daily gain (ADG) were collected and used for analysis of MC4R gene. Sixty blood samples were collected for DNA isolation and PCR amplification. The single nucleotide polymorphisms (SNP) g.1133 C $>\mathrm{G}$ was used for genotyping by using PCR-RFLP methods. The frequenciy of $\mathrm{G}$ allele $(0.59)$ was greater than $\mathrm{C}$ allele $(0.41)$. The highest genotype frequencies have been detected in CG heterozygote animals $(0.52)$ followed by GG $(0.33)$ and $\mathrm{CC}(0.15)$ in homozygote animals. The results of Pearson 's Chi-square test indicated that the population was not deviate $(\mathrm{P}>0.05)$ from the Hardy-Weinberg equilibrium (HWE). The SNP g. 1133 $\mathrm{C}>\mathrm{G}$ of MC4R gene indicated affecting high birth body length with $\mathrm{GG}$ genotype $(\mathrm{P}<0.05)$. In
\end{abstract}


conclusion, the SNP g. $1133 \mathrm{C}>\mathrm{G}$ may can be a marker for birth body length of calf selection.

Keywords: Kebumen Ongole Grade cattle, MC4R gene, body weights, body measurements

\section{INTRODUCTION}

Indonesia has a lot of local beef cattle which has experienced selection of tropical climate and low quality of feed (Sutarno and Setyawan, 2015). One of the local cattle which very famous in this country is Ongole grade cattle or Peranakan Ongole (PO). Historically, they have brought to Sumba Island in the $20^{\text {th }}$ century by the government to breed and now they are known as Sumba Ongole cattle (Hardjosubroto, 2004). Ongole grade cattle is the result of an uncontrolled mating and a grading up of Java and Sumba Ongole cattle (Suyadi et al., 2014, Hardosubroto, 1994). In Kebumen, Central Java, PO cattle genetic improvement program have been done before 1930s (Utomo et al., 2015). Kebumen also become as one of the breeding center of PO cattle (DGLSAH, 2015). The PO cattle have white-gray color body, large head, neck, black splotches on the knees, black spot circled in eyes, big body, big hump, long legs and wattle loose at the neck to stomach. Their weight gain reached 0.4-0.8 $\mathrm{kg}$ per day (Wiyatna et al., 2012).

Kebumen Ongole grade cattle have been registered by Indonesian Agricultural Ministry (No.358/Kpts/PK.040/6/2015). The productivity of Kebumen Ongole grade cattle should be increased by selection. Both body weight and body size are economic traits which recommended in selecting a cattle. Selection could be done based on quantitative or molecular data.

Recently, the molecular research has been widely developed. DNA information could be used to identify animals which had good productivity (Allan and Smith, 2008). The knowledge of genetic polymorphisms in different quantitative traits affecting economic traits in animal was essential (Cheong et al., 2006). Molecular marker associated with a certain location in the genome and could be used in identifying the partial DNA sequence (Chauhan and Rajiv, 2010). The identification of genetic markers associated with such traits also can contribute to an increased rate of genetic gain in farmed animals (Seong et al., 2012). The use of genetic markers also takes into consideration most of the factors that may affect the breeding program (Mirkena et al., 2010). The application of marker-assisted selection in the cattle can be used for genetic improvement of economic traits and breeding strategy in the breeding company (Choi et al., 2007).

The genetic polymorphisms in different quantitative traits affecting economic traits in animal was essential (Cheong et al., 2006). Identifiying the association between genetic markers and those traits could contribute to an increased rate of genetic gain in farmed animals (Seong et al., 2012). A molecular selection marker in the cattle can be used for evaluating farm animal genetic diversity and genetic improvement for economic traits in the breeding company (Chauhan and Rajiv, 2010; Choi et al., 2007). Molecular markers could be associated with traditional selection and thus help to choose the superior animals (Singh et al., 2014).

MC4R gene was known as an important candidate gene for the growth traits (Seong et al., 2012). The gene could activate adenylate cyclase and inhibit the food intake (Liu et al., 2009). MC4R gene also predicted to regulate body composition and insulin activity (Fehm et al., 2001; Obici et al., 2001). The melanocortin pathway started by leptin and insulin activate the POMC-neurons in the arcuate nucleus and produce the $\alpha-\mathrm{MSH}$. It also will activate the MC4R receptor in the paraventricular nucleus. A separate group of neurons expresses the orexigenic neuropeptide Y (NPY) and the agoutirelated protein (AGRP), which can be an inhibitor of melanocortin 3 (MC3R) and MC4R receptors. Then POMC will derive peptides depends on the type of endoproteolytic enzyme. The presence of the PC1 enzyme will produce ACTH (adrenocorticotropic hormone) and $\beta$-lipotrophin peptides, while the combined presence of $\mathrm{PC} 1$ and PC2 in the hypothalamus controls the production of $\alpha-, \beta-, \gamma$-MSH and $\beta$ endorphins. The MC4RAGRP bond sends an orexigenic signal that will increase food intake (feed intake). While the MC4R and alpha MSH bonds will send anorexigenic signals that decrease feed intake (Huvene and Dubern, 2014).

Previous research reported that MC4R gene was associated with obesity in human, serum triglyceride and energy expenditure (Dempfle et al., 2004; Bronner et al., 2006; Zobel et al., 
2009). Many studies have been reported that MC4R also associated with economic traits in some animals. Study about melanocortin gen also have done before in Magelang ducks and Ettawa goats (Rahayu, et al., 2015; Maharani et al., 2016). The melanocortinergic system has been detected in association with body weight in the agouti mouse (Chen et al., 2004). MC4R gene could activate leptin signaling for food intake and body weight in Mice(Marsh et al., 1999). The SNP C1069G in MC4R gene was associated with body weight and carcass weight in Qinchuan cattle (Liu et al., 2010). The identification and association of MC4R gene with body weight and body size in Kebumen Ongole grade cattle have not been reported. For that reason, this study was very valuable to be performed.

\section{MATERIALS AND METHODS}

\section{Animals and Data Collection}

Sixty blood samples of Kebumen Ongole grade cattle were used for this study. The animals originated from the district of Klirong consisting Tanggulangin, Pandan Lor, Kedungsari, Gebangsari and Tambak Progaten village arise from a group of farmers. About $3 \mathrm{ml}$ of blood samples were collected for genomic DNA isolation using $\mathrm{gSYNC}^{\mathrm{TM}} \mathrm{DNA}$ Extraction Kit (Geneaid). Growth data, such as birth weight (BW), weaning weight (WW), birth body length (BBL), birth chest circumference (BCC), birth shoulder height (BSH), weaning body length (WBL), weaning chest circumference (WCC), weaning shoulder height (WSH) and average daily gain (ADG) were obtained from Farmers Association recording and, used for analysis and associated with MC4R gene.

\section{DNA amplification by Polymerase Chain Reaction (PCR)}

The primer sequences according to Seong et al. (2012) for PCR amplification and the restriction enzyme for PCR-RFLP are shown in
Table 1. Polymerase chain reaction (PCR) was performed in $20 \mu \mathrm{l}$ volumes, each reaction containing $2 \mu \mathrm{l}$ DNA product, $2 \mu \mathrm{l}$ 10xbuffer, 1.6 $\mu 1 \mathrm{dNTP}, 0.2 \mu \mathrm{l}$ Taq DNA polymerase, $0.8 \mu$ forward primer, $0.8 \mu$ reverse primer and $12.6 \mu \mathrm{l}$ Double Distilled Water (DDW). PCR conditions were $5 \mathrm{~min}$ at $94^{\circ} \mathrm{C}$ for pre-denaturation and 35 cycles of $30 \mathrm{~s}$ at $94^{\circ} \mathrm{C}$ for denaturation, $30 \mathrm{~s}$ at $58^{\circ} \mathrm{C}$ for annealing, $30 \mathrm{~s}$ at $72^{\circ} \mathrm{C}$ for extension, and $10 \mathrm{~min}$ at $72^{\circ} \mathrm{C}$ for final extension using a Parkin Elmer Thermal Cycler PCR system. The PCR products were visualized by $1.5 \%$ standard agarose gels stained with ethidium bromide.

\section{Genotyping by PCR-RFLP}

The SNP g.1133 C > G identified by Seong et al. (2012) was confirmed based on the electrophoregram based on sequencing results by PT Genetics Science Indonesia with the same primers for PCR in Kebumen Ongole grade cattle. The sequences results were analyzed with the BioEdit program ver. 7.00 (Tom Hall, Ibis Therapeutics, California, USA). The SNP g.1133 $\mathrm{C}>\mathrm{G}$ was used for genotyping by the PCRrestriction fragment length polymorphism (PCRRFLP) method with HpyCH4IV restriction enzyme. The PCR-RFLP was performed in $20 \mu \mathrm{L}$ reaction volumes with approximately $15 \mu \mathrm{L}$ of PCR products, $2 \mu \mathrm{L} 10 x$ buffer, $0,5 \mu \mathrm{L}$ restrisction enzim and $2,8 \mu \mathrm{L}$ DDW . The digested products were run on $4 \%$ agarose gels.

\section{Statistical Analysis}

Allele and genotype frequencies were calculated by a simple allele counting method. Pearson's Chi-square test was used to verify the Hardy-Weinberg equilibrium status for the allele and genotype frequencies. The following mathematical model was:

$$
\mathrm{X}^{2}=\sum \frac{\left(\mathrm{O}_{\mathrm{i}}-\mathrm{E}_{\mathrm{i}}\right)^{2}}{\mathrm{E}_{\mathrm{i}}}
$$

where, $\mathrm{X}^{2}$ is Chi-square test value, Oi is observed frequency, $\mathrm{Ei}$ is expected frequency, $\mathrm{n}$ is the

Table 1. Primers for PCR Amplification and Restriction Enzyme Information for Genotyping of MC4R Gene

\begin{tabular}{cccc}
\hline GenBank & \multicolumn{1}{c}{ Primer } & PCR product size & Restriction Enzyme \\
\hline \multirow{2}{*}{ EU366350.1 } & F: 5'-GTCGGGCGTCTTGTTCATC-3' & & \\
& R : 5'-GCTTGTGTTTAGCATCGCGT-3' & $493 \mathrm{bp}$ & HpyCH4IV \\
\hline
\end{tabular}


number of possible outcomes of each event. The association of MC4R genotypes with body weight and body size in Kebumen Ongole grade cattle was an analysis with (SPSS v 22) using the following model:

$$
Y i j=\mu+T i+\varepsilon i j
$$

where $\mu$ is an average of the population, $\mathrm{Ti}$ is the effect of $\mathrm{K}$-individual and eij is the effect of random error.

\section{RESULTS AND DISCUSSION}

The SNP $1133 \mathrm{C}>\mathrm{G}$ of MC4R gene was initially detected by direct sequencing using DNA products pool by 1st Base DNA Sequencing
Service (Malaysia) as presented in Figure 1a. The SNP was used for genotyping by using PCRRFLP methods with HpyCH4IV restriction enzyme. Animals having homozygote $\mathrm{CC}$ were defined when the fragment size being recognized at 493, while homozygote GG was 173 and 320 bp. The heterozygote CG was existed by PCRRFLP method at the same position of the homologous chromosome with 173, 320 and 493 bp of fragment size (Figure 1b). As a results, most of the animals in this study had heterozygote of CG (0.52) followed by GG (0.33) and CC (0.15) genotypes. The allele and genotype frequencies are presented in Figure 2.

The result of PCR-RFLP indicated $\mathrm{C}$ and $\mathrm{G}$

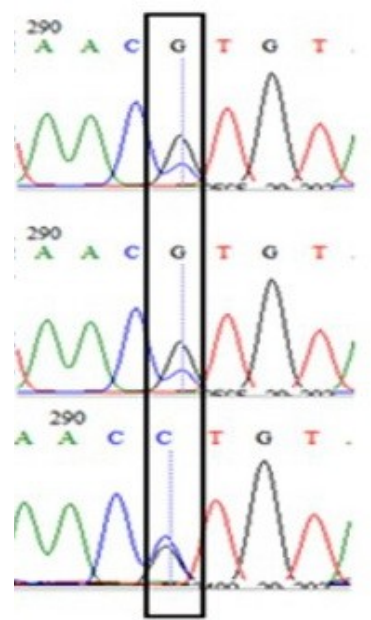

(a)

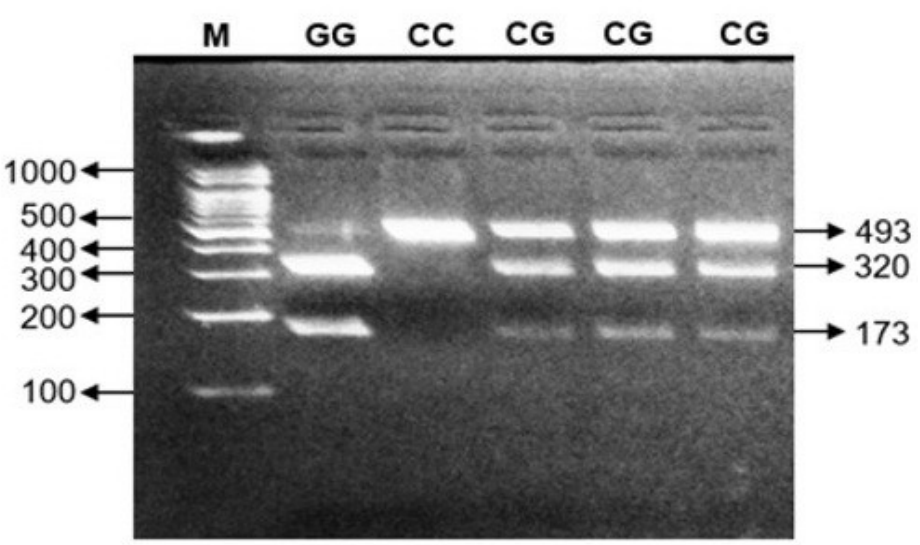

(b)

Figure 1. (a) Electrophoregram Result for the Identified SNP g.1133C $>$ G in MC4R Gene, (b) PCRRFLP Patterns of SNP g.1133C $>$ G (Digested with HpyCH4IV)

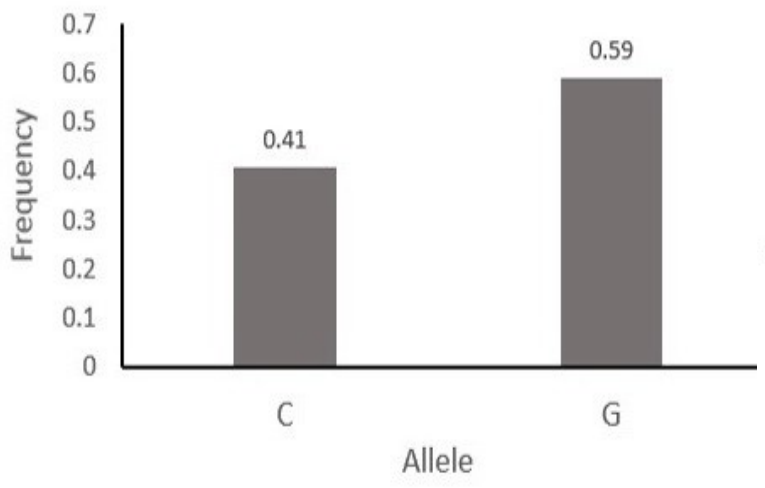

(a)

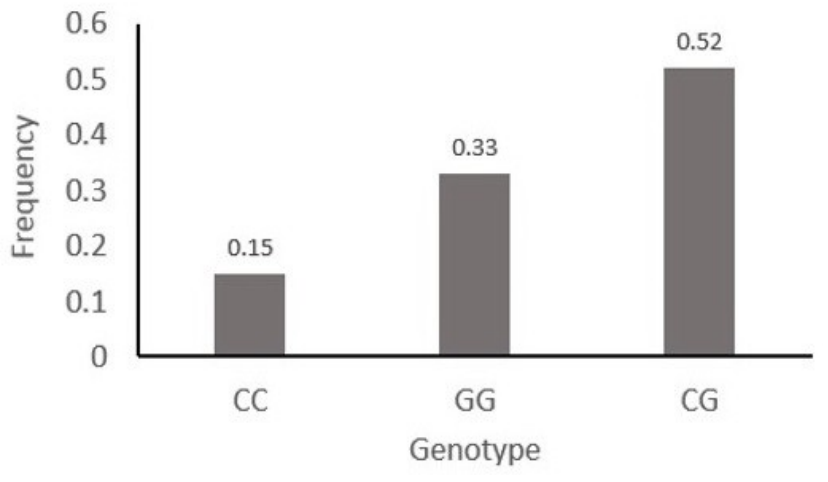

(b)

Figure 2. (a) The Allele Frequencies and (b) The Genotype Frequencies of Ongole Grade Cattle based on MC4R Gene with PCR-RFLP Methods using SNP g.1133 C > G 
alleles (Figure 2a) $\mathrm{G}$ allele (0.59) frequency was higher than the $\mathrm{C}$ allele $(0.41)$. The allele frequencies in the population showed polymorphic. The polymorphic are because of the frequency of the common allele ( $\mathrm{G}$ allele) was not more than 0.99. Harris (1994) reported if the common allele frequency of a gene was not higher than 0.99 , the cattle population will be indicated as polymorphic. Individuals GG were characterized by fragment size of 173 and $320 \mathrm{bp}$, homozygote $\mathrm{CC}$ were defined when one fragments size being recognized at 493, and heterozygote $\mathrm{CG}$ was recognized by three fragment size 173, 320 and $493 \mathrm{bp}$. The result of the genotype frequencies (Table 2) showed that the frequencies of $\mathrm{G}$ allele were greater than $\mathrm{C}$ alelle. The highest genotype frequencies have been detected in CG (52\%) heterozygote animals followed by GG (33\%) and CC (15\%) homozygote animals (Fig. 2b). The results of Pearson 's Chi-square test indicated that the genotypes of the cattle were not deviated $(\mathrm{P}>0.05)$ from the Hardy-Weinberg Equilibrium (HWE) (Table 2). Base on The Hardy-Weinberg equilibrium, this study gives the sense that the allele and genotype frequencies will be constant from one generation to the next generation as long as there were no unconditional factors, selection, mutations, migration, and inbreeding in these populations randomly (Warwick et al., 1990).

The genotypes of Kebumen Ongole grade cattle in this study were associated with 9 traits of phenotypic data using One-way Anova. The SNP g.1133 $\mathrm{C}>\mathrm{G}$ of MC4R gene was significantly

Table 2. The Genotype and Allele Frequency, and Pearson 's Chi-square Test

\begin{tabular}{|c|c|c|c|c|c|c|c|}
\hline \multirow{2}{*}{ Variable } & \multirow{2}{*}{ Total } & \multicolumn{3}{|c|}{ Genotype } & \multicolumn{2}{|c|}{ Allele } & \multirow{2}{*}{$X^{2}$} \\
\hline & & $\mathrm{CC}$ & GC & GG & $\mathrm{C}$ & G & \\
\hline \multirow[t]{2}{*}{ Birth body weight/size } & Observed & 9.00 & 31.00 & 20.00 & 0.41 & 0.59 & 0.29 \\
\hline & Expected & 10.09 & 29.03 & 20.89 & & & \\
\hline
\end{tabular}

$\mathrm{X}^{2}{ }_{0.05,2}=5.99$

Table 3. The Results of Association Analysis between Genotype and Body Weight and Body Size in Kebumen Ongole Grade Cattle based on SNP g.1133 C >G

\begin{tabular}{lccc}
\hline \multirow{2}{*}{ Variable } & \multicolumn{3}{c}{ Genotype } \\
\cline { 2 - 4 } & $\mathrm{CC}(\mathrm{n}=9)$ & $\mathrm{CG}(\mathrm{n}=31)$ & $\mathrm{GG}(\mathrm{n}=20)$ \\
\hline BW $(\mathrm{cm})$ & $31.88 \pm 3.78$ & $31.47 \pm 2.69$ & $31.64 \pm 4.16$ \\
BSH $(\mathrm{cm})$ & $74.91 \pm 5.30$ & $72.40 \pm 6.66$ & $74.13 \pm 5.87$ \\
BBL $(\mathrm{cm})$ & $59.47 \pm 5.77^{\mathrm{a}}$ & $65.43 \pm 7.21^{\mathrm{b}}$ & $66.34 \pm 6.73^{\mathrm{b}}$ \\
BCC $(\mathrm{cm})$ & $75.01 \pm 3.52$ & $75.93 \pm 4.85$ & $75.85 \pm 5.18$ \\
WW $(\mathrm{cm})$ & $93.96 \pm 21.65$ & $94.46 \pm 21.02$ & $86.63 \pm 10.60$ \\
WSH $(\mathrm{cm})$ & $71.39 \pm 3.90$ & $68.06 \pm 7.56$ & $69.55 \pm 4.97$ \\
WBL $(\mathrm{cm})$ & $54.72 \pm 4.60$ & $56.31 \pm 7.09$ & $55.60 \pm 4.65$ \\
WCC $(\mathrm{cm})$ & $64.73 \pm 6.76$ & $63.76 \pm 4.96$ & $62.78 \pm 6.85$ \\
ADG $(\mathrm{cm})$ & $0.57 \pm 0.15$ & $0.45 \pm 0.16$ & $0.53 \pm 0.16$ \\
\hline
\end{tabular}

a,b Different superscripts in the same row indicate significantly different $(\mathrm{P}<0.05)$

$\mathrm{n}$ : number of animal 
$(\mathrm{P}<0.05)$ associated with birth body length (Table 3). The SNP g.1133 $\mathrm{C}>\mathrm{G}$ was able to transform proline amino acid into arginine, thus, it due to the difference in the expression of growth traits especially length at birth. Some SNPs of MC4R gene have been examined by the previous studies on some quantitative traits of cattle. The SNP C927T, C1069G and C1343A significantly affected body weight, daily gain, marbling score and backfat thickness in Hanwoo cattle (Zhang et al., 2006; Zhang et al., 2009; Seong et al., 2012; Lee et al., 2013). The SNP-129A $>$ G reported by Liu et al. (2009) was also associated with live weight in Qinchuan cattle. However, the SNP g. $1133 \mathrm{C}>\mathrm{G}$ have been indicated firstly in Kebumen cattle.

As a result, the cattle having highest body length at birth age have GG genotype. However, other traits such as birth weight (BW), weaning weight (WW), birth chest circumference (BCC), birth shoulder height (BSH), weaning body length (WBL), weaning chest circumference (WCC), weaning shoulder height (WSH) and ADG indicated have no significant association with the gene marker $(\mathrm{P}>0.05)$.

\section{CONCLUSIONS}

SNP marker of 1133 g. $C>G$ can be recommended as a marker in selection of livestock with superior trait especially body length at birth. We suggest the marker to be applied for selecting in Kebumen Ongole grade cattle Farmers Association to give more evidence to the farmers.

\section{ACKNOWLEDGMENTS}

The authors would like to thank to the Association of Kebumen PO Breeders (ASPOKEB) for their cooperation on collecting the blood samples and their animals recording. This research was supported by Thematic Research Grant from the Faculty of Animal Science 2015 with the contract number: 1182/J01.1.25/ KU/2015.

\section{REFERENCES}

Allan, M. F. and T. P. L. Smith. 2008. Present and future applications of DNA technologies to improve beef production. Meat Science 80:79-85.

Bronner, G., A. M. Sattler, A. Hinney, M. Soufi, F.
Geller, H. Schafer, B. Maisch, J. Hebebrand and J. R. Schaefer. 2006. The 103I variant of the melanocortin 4 receptor is associated with low serum triglyceride levels. J. Clin. Endocrinol. Metab. 91: 535-538.

Chauhan, T. and K. Rajiv. 2010. Molecular markers and their applications in fisheries and aquaculture. Adv Biosci Biotechnol. 1:281-291.

Cheong, H. S. , D. H. Yoon, L. H. Kim, B. L. Park, Y. H. Choi, E. R. Chung, Y. M. Cho, E. W. Park, I. C. Cheong, S. J. Oh, S. G. Yi, T. Park and H. D. Shin. 2006. Growth hormone-releasing hormone (GHRH) polymorphisms associated with carcass traits of meat in Korean cattle. BMC Genet. 7:35-41

Chen, M., A. Wang, J. Fu, and N. Li. 2004. Different allele frequencies of MC4R gene variants in Chinese pig Breeds. Tierz. Dummerstorf. 5: 463-468.

Choi, J. R., J. D. Oh, K. J. Cho, J. H. Lee, H. S. Kong and H. K. Lee. 2007. Identification and analysis of PIT1 polymorphisms and its association with growth and carcass traits in Korean cattles (Hanwoo). J. Emb. Trans. 22: 167-172.

Dempfle, A., A. Hinney, M. HeinzelGutenbrunner, M. Raab, F. Geller, T. Gudermann, H. Schafer and J. Hebebrand. 2004. Large quantitative effect of melanocortin-4 receptor gene mutations on body mass index. J. Med. Genet. 41:795800.

DGLSAH [Director General of Livestock Services and Animal Healths]. 2015. Guidelines for the Implementation of Strengthening Native/Local Cattle Breeding in Selected Island (Pulau Raya, Sapudi Island and Nusa Penida Island) and the Strengthening of Beef Cattle Breeding in Selected District (Siak, West Pasaman, South Lampung, Kebumen, Barito Kuala, Barru, Gunung Kidul, and Central Lombok). Director General of Livestock Services and Animal Healths, Jakarta.

Fehm, H.L., R. Smolnik, W. Kern, G.P. McGregor, U. Bickel and J. Born. 2001. The melanocortin melanocyte-stimulating hormone/adrenocorticotropin (4-10) decreases body fat in humans. J. Clin. Endocrinol. Metab. 86:1144-1148.

Hardjosubroto, W. 1994. Aplikasi Pemuliabiakan Ternak di Lapangan. Grasindo, Jakarta. 
Hardjosubroto, W. 2004. Alternatif kebijakan pengelolaan berkelanjutan sumberdaya genetik sapi potong lokal dalam sistem perbibitan ternak nasional. Wartazoa. 14 (3):93-97.

Huvene, H. and B. Dubern. 2014. Molecular Mechanisms Underpinning the Development of Obesity. Springer International Publishing, Switzerland.

Lee, Y., S. Park, H. Kim, S. K. Lee, J. W. Kim, H. K. Lee, D. K. Jeong and S. J. Lee. 2013. A C1069G SNP of the MC4R gene and its association with economic traits in Korean native cattle (brown, brindle, and black). Electron. J. Biotechnol. 16:1-5.

Liu, H., W. Tian, L. Zan, H. Wang and H. Cui. 2009. Mutations of MC4R gene and its association with economic traits in Qinchuan cattle. Mol. Biol. Rep. 37:535540.

Maharani, D., I G. S. Budisatria and Panjono. 2016. 1dentification of single nucleotide polymorphisms and allele distribution of mclr gene in different head and neck color of Ettawa grade goat. Asian J. Anim. Sci. 10(3):219-223.

Marsh, D. J., G. Hollopeter, D. Huszar, R. Laufer and K. A. Yagaloff. 1999. Response of melanocortin-4 receptor-deficient mice to anorectic and orexigenic peptides. Nat. Genet. 21:119-122.

Mirkena, T., G. Duguma and A. Haile. 2010. Genetics of adaptation in domestic farm animals: a review. Livestock Sci. 132:1-12.

Obici, S., Z. Feng, J. Tan, L. Liu, G. Karkanias and L. Rossetti. 2001. Central melanocortin receptors regulate insulin action. J. Clin. Invest. 108:1079-1085.

Rahayu, A., D. Purwatini, D. Maharani and T. Hartatik. 2015. Single nucleotide polymorphism identification and genotype analysis of melanocortin 1 receptor gene in various plumage colours Magelang ducks. Int. J. Poult. Sci. 14(14):207-212.

Seong, J., D. S. Suh, K. D. Park, H. K. Lee and H. S. Kong. 2012. Identification and analysis of MC4R polymorphisms and their association with economic traits of Korean cattle (Hanwoo). Molecular Biology Reports. 39:3597-3601.

Singh, U., R. Deb, R. R. Alyethodi, R. Alex, S. Kumar, S. Chakraborty, K. Dhama and A.
Sharma. 2014. Molecular markers and their applications in cattle genetic research: A review. Biomarkers and Genomic Medicine. $6: 49-58$

Sutarno and A. D. Setyawan. 2015. Review: Genetic diversity of local and exotic cattle and their crossbreeding impact on the quality of Indonesian cattle. Biodiv. 16:327354.

Suyadi, S., L. Hakim, S. Wahjuningsih and H. Nugroho. 2014. Reproductive performance of Peranakan Ongole (PO) and Limousin x PO Crossbreed (Limpo) cattle at different altitude areas in East Java, Indonesia. J. Appl. Sci. Agric. 9 (11) : 81-85.

Utomo, B., R. Oelviani and Subiharta. 2015. Peningkatan performa pedet sapi Peranakan Ongole pascasapih melalui perbaikan manajemen dengan pemanfaatan sumber daya lokal. Proc. Sem. Nas. Masy. Biodiv. Indon. 1: 838-842.

Warwick, E. J., J. M. Astuti and W. Hardjosubroto. 1990. Pemuliaan Ternak. Universitas Gadjah Mada Press. Yogyakarta, Indonesia.

Wiyatna, M. F., E. Gurnadi and K. Mudikdjo. 2012. Produktivitas sapi Peranakan Ongole pada peternakan rakyat di Kabupaten Sumedang. Jurnal Ilmu Ternak. 12(2):2225.

Zhang, C. L., H. Chen, Y. H. Wang, X. Y. Lan, L. Zhang, A. L. Zhang and R. F. Zhang. 2006. Association of a missense mutation of The $M C 4 R$ gene with growth traits in cattle (brief report). Arch. Tierz. Dummerstorf. 49:515-516.

Zhang, C. L., Y. H. Wang, H. Chen, X. Y. Lan, C. Z. Lei and X. T. Fang. 2009. Association between variants in the 50-untranslated region of the bovine MC4R gene and two growth traits in Nanyang cattle. Mol. Biol. Rep. 36:1839-1843.

Zobel, D. P., C. H. Andreasen, N. Grarup, H. Eiberg, T. I. Sorensen, A. Sandbaek, T. Lauritzen, K. Borch-Johnsen, T. Jorgensen, O. Pedersen and T. Hansen. 2009. Variants near MC4R are associated with obesity and influence obesity-related quantitative traits in a population of middleaged people: studies of 14,940 Danes. Diabetes. 58:757764. 